\title{
LIST OF DOCTORAL DISSERTATIONS IN POLITICAL SCIENCE
}

A list of doctoral dissertations in progress in the field of history has been compiled by Dr. J. Franklin Jameson and appears in the History Teachers' Magazine for January 1913. The list of dissertations in political economy for 1913 appeared in the American Economic Review for June, 1913. In one or other of these lists may be found most of the dissertions of interest to students of political science, but a number of political science dissertations are included in neither of them. On this account it has been thought well to publish the following list, which had been compiled partly from responses received from the several universities and partly from the published lists of historical and economic dissertations. For the year 1912 a list similar to that given below appeared in the August 1912 number of this REVIEW (vol. vi, 464).

\section{CHICAGO}

E. M. Atnos, S.B., Lima College, 1907; A. M. Clark University, 1908. The Policy of the States Toward the Trusts.

Lucia von Luck Becker, Ph. B., Chicago, 1909; Ph. M. 1911. The History of the Admission of New States into the Union.

F. B. Carver, A.B., Nebraska, 1909. History and Critical Examination of the Taxation System of Illinois.

E. F. Colbourn, A.B., Miami, 1907; A.M., Cincinnati 1908. The Republican Party in Ohio, 1854-1865.

J. F. Ebersole, Ph.B., Chicago, 190\%; A.M., Harvard, 1909. History of the National Banking System, 1864-1874.

F. B. Garver, A.B., Nebraska, 1909. The Subvention in American State Finance.

C. K. Guild, A.B., University of Manitoba, 1909. Trade Relations Between Canada and the United States.

A. P. James, A.B., Randolph-Macon 1906; A.M., Chicago, 1911. The Constitutional Responsibilities of the Secretary of the Treasury.

Hazel Kyrk, Ph.B., Chicago, 1911. The Development of State Policies of Control in the United States.

J. F. Lee, A.B., Des Moines College, 1904; A.M., State University of Lowa, 1905. Transportation as a Factor in the Development of Illinois before 1860.

D. A. MacGibbon, A.B., McMaster University, 1908. The Canadian Railway Commission and Railway Regulation.

H. A. McGill, A.B., Butler, 1902. The Congressional Caucus.

A. R. Morgan, A.B., California, 1909; A. M. Chicago, 1912. The History of Ecclesiastical Legislation Concerning Divorce, especially in Modern Times.

J. R. Robertson, A.B., Beloit, 1904. The Republican Party in Illinois, 18541872 . 
A. P. Scott, A.B., Princeton, 1904; B.D., Chicago Theological Seminary, 1910. A Comparative Study of the Criminal Legislation of Massachusetts and Virginia in Colonial Times.

A. W. Taylor, A.B., Doane College, 1902; A.M., Wisconsin, 1910. The Long and Short Haul Clause.

F. J. Tschan, A.B., St. Ignatius College, 1901; A.M., 1904. The North Sea Fisheries in the Middle Ages.

C. Vassardakis, LL.D., National University of Athens, 1910; S.D., University of Geneva. 1908. The Bank of Greece.

E. J. Woodhouse, A.B., Randolph-Macon, 1908; LL.B., Virginia, 1907. The Development of the Judicial System in Virginia before 1860.

A. H. Woodworth, A.B., Lafayette College, 1904; A.M., University of Chicago, 1906. The Sociological Valuation of the Idea of Equality in American Political Theory.

\section{COLUMBIA}

N. P. Aghnides, LL.B., Ottoman Law School, Constantinople, 1909. Mohammedan Laws of Taxation.

R. R. Ammarell, A.B., Muhlenberg, 1911; A.M., Columbia, 1912. The Politics of Pennsylvania during the Civil War and Reconstruction.

Frederick Otto Berge, LL.B., University of Nebraska, 1899; B.S., Columbia, 1909; A.M., 1910; LL.B., 1911. Governmental Control of Campaign Funds of Political Parties.

Joseph P. Chamberlain, LL.B., Hastings Law School, 1898. International Law of Rivers.

S. K. Chen, Graduate, Peking University, 1908; A.M., Columbia, 1911. The Chinese Taxation System in the 19th Century.

J. L. Deming, A.B., Cincinnati, 1889; A.M., Bethany, 1900. Immigration to the United States, 1776-1820: A Study in Causes and Effects.

W. E. Dunn, A.B., Texas, 1909; A.M., Leland Slanford 1910. The Office of President in the Spanish-American Republics.

G.W. Edwards, A.B., College of the City of New York,1911. New York as an Eighteenth-Century Municipality, 1730-1776.

W. M. Feigenbaum, A.B., Columbia, 1907; A.M., 1908. Ratification of the Federal Constitution in New York.

Lucius Arnold Frye, A.B., University of Minnesota, 1907; A.M., 1908; B.C.L. (Oxon.), 1911. History of the State Control of Public Service Corporations in New York.

Miss Floy Victoria Gilmore, LL.B., University of Michigan, 1901; A.B., University of Washington, 1910. Marriage License Regulation.

S. E. Hall, A.B., Vermont, 1907; A.M., Columbia, 1911. The Development in Roman and in English Law of an Implied Warranty of Quality in Goods Sold. H. H. Holmes, Ph.B., Alabama Normal, 1904. History of the Denominational Control of Education in the United States.

Sydney D. Moore Hudson, Ph.B., Syracuse, 1907. The Power of Congress over Interstate Commerce.

C. L. F. Huth, A.B., Wisconsin, 1904; A.M., 1905. The Right of Asylum. 
Akira Izumi, A.B., Lake Forest College, 1907; A.M., University of Wisconsin, 1908. International Police Power.

Irwin G. Jennings, LL.B., Ohio State University, 1899; A.B. and A.M., Marietta College, 1910. Labor Legislation and the Police Power.

B. B. Kendrick, B.S., Mercer, 1905. The Work of the Joint Committee on Reconstruction, 1866-1867.

E. P. Kilroe, A.B., Columbia, 1904; A.M., 1905, LL.B., 1906. The Origin and Development of the Society of Tammany in the City of New York.

Samuel Simon Laucks, A.B., Ursinus,1910. The Pennsylvania Legislature: A Study of the Representative System.

Y. C. Ma, A. B., Yale, 1910. Public Finances of Greater New York.

Leonard Jerome Matteson, A.B., Colgate, 1911; A.M., Columbia, 1912. Judicial Control over Legislation in New Jersey.

Lewis Mayers, A.B., College of the City of New York,1910; A.M., University of Wisconsin, 1912. The New York City School Board. 1913.

Charles Harrison Meyers, A.B., Columbia, 1912. Constitutionality of Workmen's Compensation Acts.

Robert Moses, A.B., Yale, 1909; A.B. (Oxon.) Juris., 1911. The Civil Service of Great Britain. 1913.

J.E. Oster, Litt.B., Ohio Northern University, 1909; LL.B., 1909. The Political and Economic Doctrines of John Marshall.

Charles Pearle, A.M., Columbia, 1913. Judicial Control over Legislation in New York.

A.E.Peterson, A.B., Tufts, 1888; A.M., 1892. New York as an Eighteenth Century Municipality to 1730 .

R. R. Powell, A. B., Rochester, 1911. The Development in Roman and in English Law of Remedies against Fraud.

E. R. Russell, Ph.B., Vermont, 1906. Action of the Privy Council on Colonial Legislation.

Birl E. Schulz, A.B., DePauw, 1909; A.M., Columbia, 1911. Justice McLean and the Dred Scott Decision.

J. N. Sokohl, B. S., Teachers College, 1912. State Bureaus of Conciliation and Arbitration.

H. A. Stebbins, Ph.B., Syracuse, 1906; Ph.M., 1907. Party Politics in New York State after 1865.

K. K. Steffensen, A.B., University of Utah, 1911; A.M., Columbia, 1912. The Juristic Effect of a Decision Declaring a Statute Unconstitutional.

\section{CORNELL}

E. D. Ross, Ph.B., Syracuse, 1909; Ph. M., 1910. The Liberal Republican Movement.

M. B. Foster, A.B., Carson and Newman, 1910; A.M., 1911. A History of Banking in the State of New York.

C. C. Huntington, B.S., Antioch, 1896; Ph.B., Ohio State 1902; A.M., 1909. A History of Banking and Currency in Ohio Prior to the Civil War.

F. M. Simons, Jr., A.B., Swarthmore College, 1909; A. M., 1912. Interlocking Directorates, Their Effect upon Cost of Service of Common Carriers. 
R. M. Woodbury, A.B., Clark College, 1910; A.M., Clark University, 1912. State and Federal Systems of Old-age Pensions in the United States.

\section{HARVARD}

Daniel Huger Batco, Jr., A.B. and A. M., College of Charleston; A.M., Harvard University. The South Carolina Land System in relation to its Political and Social Institutions.

Arthur Edward Romilly Boak, A.M., Queen's University; A.M., Harvard University. The Magistri of the Roman Republic and Empire.

Harold Hichens Burbank, A.B. and A.M., Dartmouth College. The History of the General Property Tax in Massachusetts since 1775.

Kenneth Wallace Colgrove, A.B. and A.M., University of Iowa. The History of Legislative Instructions in the United States.

Edwin Angell Cotirell, A.B., Swarthmore College. The Government of Newport, Rhode Island.

Charles Claflin Davis, S.B. and LL.B., Harvard University. The Nature of Law.

Edwin DeWitt Dickinson, A.B., Carleton College; A.M., Dartmouth College. The Equality of States.

Clifton Rumsey Hall, A.B., Amherst College; A.M., Harvard University. The Secretary of State as a Diplomat.

Thomas LeGrand Harris, A.B. and A.M., Indiana University. The Trent Affair, including a Review of English and American Relations at the beginning of the Civil War.

Orren Chalmer Hormell, A.B. and A.M., Indiana University; A.M., Harvard University. Reasons for Negro Suffrage.

Henry Horwitz, A.B. and A.M., Harvard University. Change of Sovereignty in International Law.

Yamato Ichihashi, A.B. and A.M., Leland Stanford Junior University. Japanese Emigration and their Immigration into the State of California.

John Ise, A.B. and LL.B., University of Kansas. The Government Land Policy since 1880.

Theodore Henley Jack, A.B. and A.M., University of Alabama. The Opposition to Secession in Alabama.

Harley Leist Lutz, A.B., Oberlin College; A.M., Harvard University. State control over the Assessment of Property for Local Taxation.

Stuart Cameron McLeod, A.B. and A.M., Toronto University. The Government of Canadian Cities.

James Blair Newell, A.B., Leland Stanford Junior University; A.M., Harvard University. The Slavery and Disunion Questions in California.

Johann Gottfried Ohsol, Candidate of Commercio, Riga Polytechnic Institute (Russia). Political Activities of the American Labor Unions.

Lawrence Bradford Packard, A.B., Harvard University. Economic Aspects of the French Royal Policy, 1700-1756,

Edwin William Pahlow, B.L., University of Wisconsin; A.M., Harvard University. The Revocation of the Borough Charters by the Stuarts.

Dexter Perkins, A.B., Harvard University. The Monroe Doctrine in its European Aspect. 
Robert Jackson Ray, A.B., and A.M., University of Kansas. The History and Policies of Rural Highway Control in the United States.

Walter James Shepard, A.B., Harvard University. Ministerial Responsibility. (Completed).

Emil Sauer, B.Lit., University of Texas; A.M., Harvard University. The Reciprocity Treaty of 1875 and the Relations between the United States and Hawaii, 1875-1908.

Carl Stephenson, A.B., and A.M., De Pauw University. The Military Relations of the Boroughs to the Crown in England.

George Malcolm Stephenson, S.B., University of Chicago; A.B., Augustana College; A.M., Harvard University. The History of Politics and Public Lands from 1841 to 1862.

Russell McCulloch Story, A.B., Monmouth College; A.M., Harvard University. The Office of Mayor in the United States.

Rufus Stickney Tucker, A.B., and A.M., Harvard University. The Incidence of Real Estate Taxation.

George Henry Von Tungeln, Ph.B., Central Wesleyan College; A.M., Northwestern University. Boston Juvenile Offenders in their Economic and Moral Relations.

Raynor Greenleaf Wellington, A.B., and A.M., Harvard University. The Political Influence of Public Lands, 1825-1842.

Ralph Cahoon Whitnack, A.B., Brown University; A.M., Harvard University. The Income Tax.

Henry Merritt Wriston, A.B., and A.M., Wesleyan University. Lahmen to Justitia: a study in the development of a Common Law in England.

\section{ILLINOIS}

D. O. Clark, A.B., Drury, 1890; A.M., Illinois, 1909. Stein's Principles of Administration.

G. W. Dowrie, A.B., Lake Forest College, 1901; A.M., Chicago, 1907. The Development of Banking in Illinois, 1819-1863.

Chester A. Hanford, A.B., University of Illinois, 1912. A.M., 1913. Municipal Government in Illinois.

Julius Goebel, Jr., A.B., University of Illinois, 1912; A.M., 1913. History and Policy of the United States in respect to Recognition in International Law.

J. E. Miller, A.B., Kansas, 1910. Benefit of Clergy in England.

Quincy Wright, A.B., Lombard College, 1912; A.M., University of Illinois, 1913. The Extent to which the Principles of International Law have been incorporated into the Municipal Law of the United States.

\section{IOWA}

Sudhindra Bose, A.B., Illinois, 1907; A.M., 1909. Some Phases of British Administration in India.

H. J. Peterson, A.B., St. Olaf, 1905; Iowa, 1907. Methods of Choosing Public Officials in Iowa.

\section{JOHNS HOPKINS}

F.B.Clark, A.B., Richmond College, 1907; A.M., 1908. The Constitutional Doctrines of Justice Harlan as Stated in His Dissenting Opinions. 1914. 
J. L. Donaldson, C.B., Maryland Agricultural College, 1910. State Administration in Maryland. 1914.

C. G. Fenwick, A.B., Loyola College, 1908; A.M., 1909. The Neutrality Laws of the United States. Completed.

K. R. Greenfield, A.B., Western Maryland, 1911. Paternal Government in Mediaeval Cities of the Lower Rhine.

W. B. Hunting, A.B., Johns Hopkins, 1909. The Impairment of the Obligation of Contracts. Completed.

S. Kitasawa, A.B., Waseda, 1910; A.M., North Carolina, 1911. History and Growth of National Indebtedness of the United States and Japan.

J. M. Leake, A.B., Randolph-Macon, 1902. The Committee System of the American Revolution.

O. L. Owens, A.B., Richmond College, 1898. The Protection of American Foreign Missionaries by the United States.

L. Rogers, A.B., Johns Hopkins, 1912. The Postal Power of Congress.

H. W. Steele. Labor Legislation in Maryland.

T. Yokoyama, Ph.B., Kansas City University, 1909. The Japanese Judiciary.

\section{LELAND STANFORD}

W. E. Cox, A.B., Texas, 1910;A.M., 1910. The Commercial Relations of the United States and Japan.

Mary Williams, A.B., Leland Stanford, 1907; A.M., 1908. The Relations of England and America in Central America since 1815.

\section{MICHIGAN}

C. S. Boucher, A.B., Michigan, 1909; A.M., 1910. South Carolina Politics 1834-1861.

W. H. Hamilton, Ph.D., Michigan, 1918. The Mediaeval Ideal of Authoritative Control: A Study in the Relations of Social Values and Industrial Development.

J. R. Hayden, A.B., Knox College, 1911; A.M., Michigan, 1912. The Treaty Making Power of the Senate.

F. B. Streeter, A.B., Kansas, 1911; A.M., 1912. History of Political Parties in Michigan 1844-1860.

\section{NEW YORK}

H. J. Ackerman, A.B., Syracuse, 1901; A.M., New York, 1909. A Sociological Study of the Roman-Teutonic Conception of Property.

A. O. Miller, Jr., A.B., Columbia, 1893; LL.B., 1895; LL.M., 1896; J.D., New York, 1908. Local Government in New York during the Revolution.

A. G. Warren, A.B., Rochester, 1883; A.M., New York, 1909. A Comparison of the Tendencies in Constitutional Construction shown by the Supreme Court under Chief Justices Marshall and Taney respectively.

\section{PENNSYLVANIA}

C.E. Asnis, A.B., Pennsylvania, 1904; LL.B., 1907. Scope and Purpose of the Amendments to the State Constitution of Pennsylvania, with special Reference to the Present Need for Constitutional Revision. 
P. H. Clements, A.B., Indiana, 1911; A.M., 1912. China's Relations with the Powers since 1895.

H. W. Hoagland, B.S., Pennsylvania, 1911. Napoleon's Coast System.

P. Hoekstra, A.B., Michigan, 1910;A.M., 1911. The Relations between the United States and the Netherlands, 1783 to 1830.

O. E. Hooley, A.B., Wisconsin, 1910; A.M., 1912. Proposals to Amend the Articles of Confederation.

H. M. Louis, A.B., George Washington, 1912. Development of Spheres of Influence in China.

J. C. McGregor, B.S., Washington and Jefferson, 1905; A.M., 1908. The Separation of West Virginia from Virginia.

F. E. Melvin, A.B., Kansas, 1906. The License System during the Napoleonic Era.

J. Tanger, Ph.B., Franklin and Marshall, 1909; A.M., Pennsylvania, 1912. Proposed Amendments to the Constitution of the United States since 1889.

\section{WISCONSIN}

J. M. Atwood, A.B., Wisconsin, 1910. International Relations of the Central American States.

W. L. Bailey, A.B., Queen's (Toronto), 1904. A Comparative Study of County Government.

Marie Paula Dickor, A.B., Cincinnati, 1907; A.M., 1908. The Public Land System in the Thirties.

E. H. Downey A.B., Iowa, 1907; A.M., 1908. History of Indemnity for Work Accidents in Iowa.

H. C. Hockett, A.B., Wisconsin, 1903. Political Parties in the United States from 1815 to 1825 .

Lorian P. Jefferson, Litt.B., Laurence, 1893; A.M., Wisconsin, 190\%. History of the Movement for Shorter Hours.

O. G. Jones, B.S., Ohio Wesleyan, 1912. The Development of Self-Government in the Philippine Islands since the American Occupation.

W. I. King, A.B., Nebraska, 1905; A.M., Wisconsin, 1910. Valuation of Urban Realty for Purposes of Taxation.

J. E. Kirshman, Ph.B., Central Wesleyan, 1904; Ph.M., Syracuse, 1908. The Modern Doctrine of Protection, 1880-1890.

H. T. Lewis, A.B., Lawrence, 1910; A.M., Wisconsin, 1911. An Analysis of Economic Elements Embodied in the Wisconsin Railway Commission.

Reuben McKitrick, A.B., Oklahoma, 1907. Legislative Disposition of Public Land in Texas.

H. C. Nordlie, A.B., Luther, 1906; A.M., Wisconsin, 1908. History of Elections in Minnesota, 1873-1896.

E. E. Robinson, A.B., Wisconsin, 1908; A.M., 1910. Political Grouping 18321840: The Rise of the Whig Party.

H. R. Trumbower, A.B., Lehigh, 1903; A.M., Princeton, 1908. Urban Lands and Land Speculation in Germany and America.

C. B. Tsai, A.B., Wisconsin, 1910. Extraterritoriality in China.

E. E. Witte, A.B., Wisconsin, 1909. The Development of the Law of Labor Combination in the United States. 


\section{YALE}

W. O. Ault, A.B., Baker, 1907; B.A., Oxford, 1910. The Private Court in England.

A. H. Basye, A.B., Kansas, 1904; A.M., 1906. The office of Secretary of State for America.

P. L. Gillette, A.B., Colorado College, 1897; A.M., Yale, 1909. The History of Corean Gilds.

R. V. Harlow, A.B., Yale, 1909; A.M., 1911. The History of Legislative Committees, $1750-1800$.

R. B. Munson, Ph.B., Yale, 1909; A.M., 1911. The Growth of Assembly Control in New York, $1700-1760$.

W. A. Robinson, A.B., Bowdoin, 1907; A.M., Wisconsin, 1910. The Republican Party in New England, 1793-1815. 